The International Conference : Cities' Identity Through Architecture and Arts (CITAA)

\title{
Identity of the industrial cities
}

\author{
DOI: $10.21625 /$ archive.v1i1.110
}

\section{Haitham Aamer Mahmoud Hussein ${ }^{1}$}

\author{
${ }^{1}$ Lecturer at Sculpture department, Faculty of Fine Arts, University of Mansoura
}

\begin{abstract}
Keywords
Identity-the industrial citiesTwentieth century- GlobalizationCivilization- Development Contemporary Arts- Historical Economic - Political - Religious Scientific- Machine- MakersSymbol-Belonging - Motherland
\end{abstract}

\begin{abstract}
It is clear how the techonological developments along with globalization depleted the identity of civilizations and peoples, so it is necessary for the intellectuals and the artists to work hard in order to assure the identity of the cities. Such sacred goal could be achieved via increasing the people's awareness.

The identity of the cities will, directly, help in achieving the elevation and excellence of cities in order to maintain the uniqueness of their personalities and artwroks. In doing so, sublime values and morals, like the spirit of nationalism and patriotism of their people will be cultivated and harnessed. However, neglecting that may result in the dismantling of their identity accompanied by other sideaffects, like losing the cities' historical, economic, political, social, religious or scientific identity.

This study is analysing and comparing the models for a distinct identity of the industrial cities ranging from Egypt, Europe to America in the twentieth century until now. It also investigates if the contemporary arts have a role to assert a distinct identity of the industrial cities in this period of time or not.
\end{abstract}

Art is the language of the place and the revealer of its identity. Statues in squares are a pulpit. Urban spaces help cultivating such language emphasizing of the culture of its residents and the policy of the responsible administrations. Technical works in the industrial cities represents the identity of the city, which is totally different than other cities.

The identity of the industrial states is affected by several factors. Firstly, the cultural factors- where the establishments of culture and identity occur through arts, the awareness and understanding of the audience, and their tastes of the Arts. Secondly, the economic factors which cost and enrich the attraction of investors and manufacturers. Thirdly, the political factors assist the governments in seeking the elimination of the socisl problems concerning the political success. It is majorly perpetuauted by providing factories and living needs in these cities; leading to the negligience of the artsitic, social and moral factors. There should be a relationship between these borderlines and the used machinery to achieve compatibility between life circumstances and the beauty of the artwork.

Drafting Fine artwork, and its impact on manufacturers' motivation and encouragement, by expression or symbolism or movement within the artwork, and the emphasis on the moral value of the work in gaining respect and dignity.

Spatial limits : Egypt, Europe, America, and limiting the study to on one city from each.

Time limits: from the twentieth century until now. 


\section{Introduction}

This paper deals with the identity of industrial cities and the role of arts to show the identity of these cities and their importance to express the identity of places and communities that practice industrial activities and expressing their inner psychological, social motives and peoples' and communities' innermost thoughts , "Identity is a composite of standards, which allows the definition of an internal issue or feeling. The sense of identity involves a range of different emotions, such as feelings of loneliness, integration, and belonging, value, and independence, and a sense of confidence on the basis of the will of existence $"{ }^{1}$ and its important role in the recording of real life and its impact on the origination of values and raising the peoples' spirit of nationalism. Arts are the main and major influence in the lives of peoples and a main influence in the community and its cultural, intellectual convictions, to get to know their identity and heritage and beliefs and their cultural legacy.

\section{The problem of the study is stated as follows:}

- What is the impact of art asserting identity on the industrial cities?

- Did art perform its role to record the heritage or the reality of the industrial cities? Did it influence the community members or they way they express their identity?

- Is art considered as the language of place, the revealing podium of the squares and urban spaces?

\section{Research hypotheses:}

- There is a positive influence by arts on the social, cultural and national content of the industrial cities' members and arts communities

- The artist is attached to his artistic senses in realistic and symbolic recordings of the identity in the industrial cities.

\section{Delimitations of the study:}

- Time delimitations: it deals with the identity of the industrial cities in the twentieth century.

- Spatial delimitations: It studies analyses and compares models concerning the identity of the industrial cities such as Egypt, Europe and America.

\section{Study axioms:}

- Artworks bear cultural legacy of the countries and societies' personality, and they highlight the identity.

- Arts are a means to record events, date heritage, and express the identity and nationalism of nations and tribes.

- Arts influence the communal, cultural, intellectual, and convictions of the peoples in order to get to know and keep their heritage and beliefs.

\section{Research Methodology:}

Analytical-investigative field research.

\section{Significance of the study:}

- It states the importance of the role of arts in highlighting the identity of the industrial cities to influence the members of these communities.

- It reveal the ability of artists to express the reality of life and the heritage of their peoples in the form of technical work, in the squares of cities

\section{The Goals of the Study:}

- It investigates the importance of modern artworks as expressive and graphical elements in highlighting the identity of the industrial cities.

- It investigates the effectiveness of the arts' role to emphasize the privacy of the place and it shows the most important symbols associated to the identity of the place.

An overview about the Labour Day: It is a way of appreciating workers by assigning a day to commemorate the anniversary of the workers' clashes in the United States that resulted in a number of casualtie. They demanded their rights on the first of May 1886, and in 1904, the International Socialist Conference was held in Amsterdam,

\footnotetext{
${ }^{1}$ Alex Mekchelly, "Identity" , translation by Dr. Ali Watfah - 1st issue, p.15, Dar Elwaseem, Damascus, 1993
} 
and asked the trade unions and organizations to consider the first of May as a workers' celebration day. The socialist organizations tried to make it a holiday, which was already admitted by the Catholic Church in 1954, but the US government had refused their request until, under pressure, the socialist labour organizations succeeded in imposing the admission of that day to commemorate the anniversary in America, Canada, Australia and many countries, including Egypt

Egypt has taken the first of May as a holiday for workers with the establishment of the labour movement in Egypt, and the protests organized by the Federation of Workers to Alexandria in 1964 when President Gamal Abdul Nasser acknowledged this day as a holiday for workers.

\section{The Identity of the Industrial cities in America:}

Important and vital industries are grounded in America as the iron and steel industry. It is one of the oldest industries, which is found near the iron and coal mines, chemical industry, mechanical industry, including the automotive industry. It was the second largest industry after Japan, and it produced hardware rails and shipbuilding around mining centers. The shipbuilding industry was found on the coasts. The textile industry was another important one occupied by the U.S. as the first producer in the world by the vitrue of the complicated electronic industry.

Some artworks were held in several American countries and dealt with the identity of some industrial cities to stress on the role of art in determining the industrial identity. It shed the light on the role of the manufacturers and the city businesses by highlighting the value of the place and appreciating the role of the manufacturers in all fields of life.

For example, some works present the industrial activity of the workers and craftsmen, in the coal field and the oil drilling and mining ores, appear in a number of countries which has a great social, economical and political impact on all members of the industrial systems. In (Figure 1), workers move actively and strongly giving enthusiasm to those who see them and appreciate their dedication in work. It also demonstrates the activity of this town and shows its identity in drilling and processing oil. It is considered as one of the most important fields of oil production in the ${ }^{2}$ world, and the statues of the two roughnecks during oil processing is carried out by Carlos Terres circa in 2014, in Santa Fe Springs. The statue highlights the oil industry in this small town ${ }^{3}$. In (Fig. 2), we find another model for the Roughneck Bronze Sculpture " "Man Made Energy," made by the Seth Vandable. It is located in the east of Casper, Wyoming -America. The statue is a symbol of the dedication and hard work required to drill oil and gas from the ground, for the energy industry in this city represents the basis of its past and future ${ }^{4}$ (Figure 3).

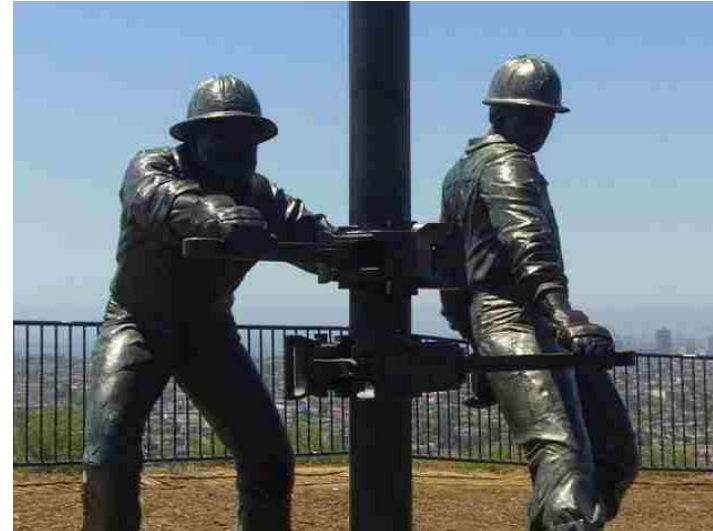

Fig. 1 a sculpture two bronze roughnecks, by the artist Cindy Jackson, SIGNAL HILL, California, USA

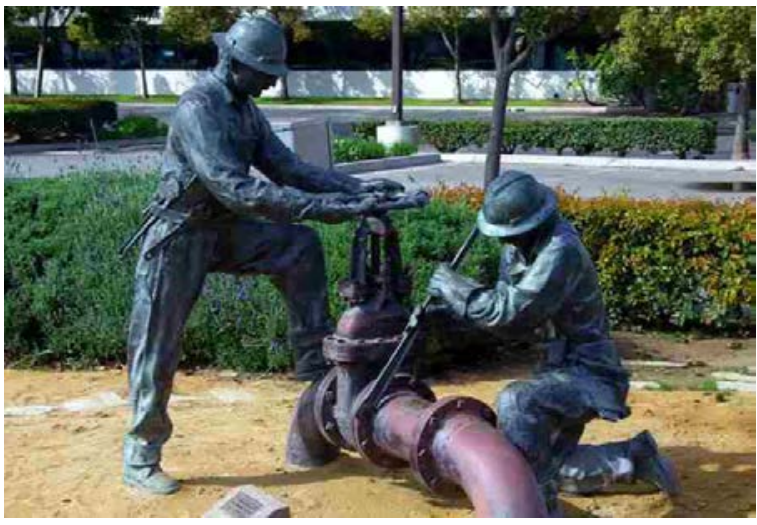

Fig 2 Oil fields workers, by the artist Carlos Terres circa, SANTA FE SPRINGS, LA, California, USA

https://translate.google.com.eg/translate?hl=ar\&sl=en\&u=https://en.wikipedia.org/wiki/Signal_Hill,_California\&prev=sear ch

${ }^{3}$ https://www.shutterstock.com/video/clip-5676593-stock-footage-santa-fe-springs-ca-february-the-oilfield-workers-

sculpture- by-carlos-terres-circa.html

${ }^{4}$ https://www.pinterest.com/pin/487585097127142718/ 


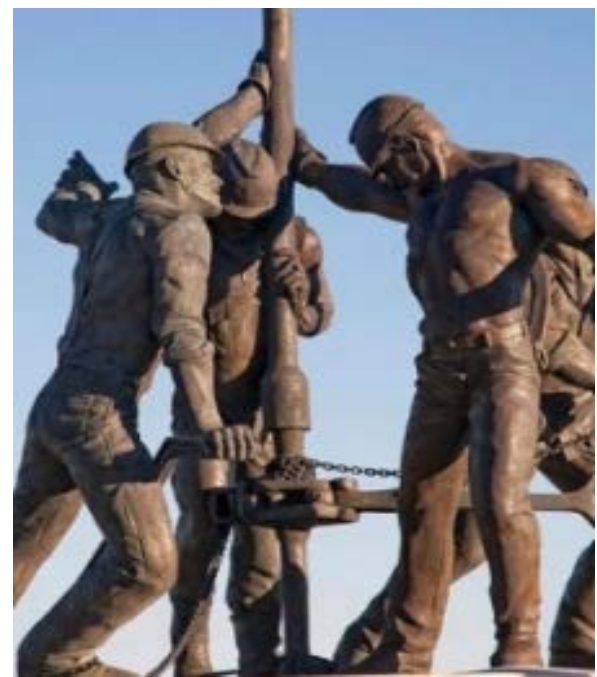

(Fig. 3) Roughneck Bronze Sculpture "Man Made Energy" by the artist Seth Vandable statues of bronze, Casper, America

The Bronze statue in Michigan, US, commemorates the makers of the Mackinac Bridge)) (Figure 4) .

In another model to show industrial activity, in one of the cities appreciating the workers, is the statue of the worker in rail-Bolivia, South America (fig 5).

Asserting the role of art in providing motivation urge and appreciate working and showing toughness, persistence and dedication of the craftsmen is shown in the monument of "mechanics" by Douglas Tilden - San Francisco, CA America ${ }^{5}$ (Fig. 6)

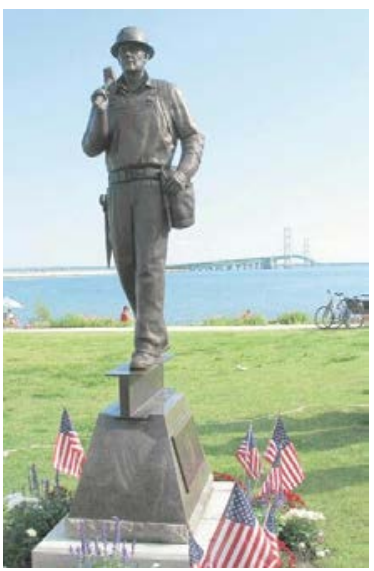

Fig. 4 the bronze statue of the Ironworker, Michigan, US, appreciating the makers of Mackinac bridge 1950

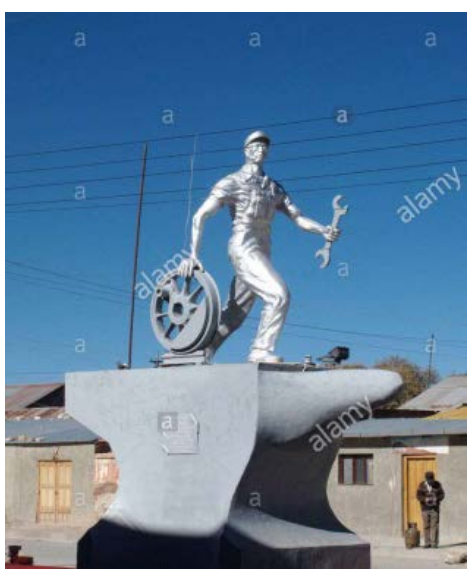

Fig 5 A rail-worker statue, Bolivia, South America

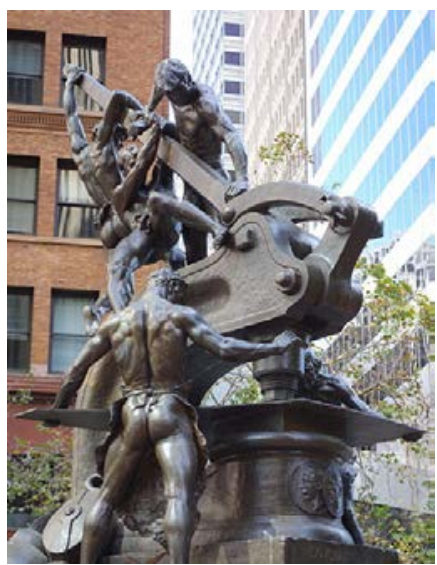

Fig 6 the MECHANICS monument, by the artist Douglas Tilden, San Francisco, USA

In another spot, we find an artwork that is a tribute to the dedication and hard work of all those who built the city of Omaha. In Nebraska, a tribute to the workers in labour unions is also present. Omaha is the second largest memorial of work in the country, unveiled in 2003. It includes four men and a woman toiling in their work, a design by the Matthew Placzek (Fig. 7).

Iowa is the thirty-eighth state to create a memorial to its workers. The Creators of the idea strongly felt that it would give Iowa workers a strong code of ethics that grants Iowa the prestige for work and living. This square balanced construction is eleven feet in length and its width is four arms interlocked, thorough a scene symbolizing the energy and integrity of Iowa workers. The arms support each other ,and at the same time, and show varying shades of people from different backgrounds. They come together to form a cultural and laboural basis to Iowa, built of an ornamented bronze strips held by an internal shield of stainless steel structure in a twisted woven form that resemble muscles, nerves., function of the movement and sensation. the vast interwoven features of the building allow sunlight to shine and dance through spaces of the construction, with a constant contrast between

\footnotetext{
${ }^{5}$ https://commons.wikimedia.org/wiki/File:Mechanics_Monument_by_Douglas_Tilden_-_San_Francisco,_CA_-_DSC03542.JPG
} 
the splendor of the outer and inner building. It has a reflective depth of bronze followed by warm tunes of eart and old rust that reveals richer texture and extraordinary splendor (Fig. 8).
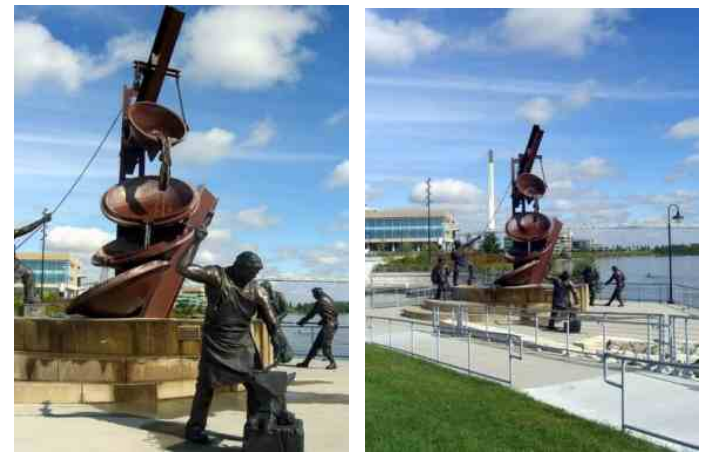

Fig. 8, A monument standing for the energy and integration of Iwa workers

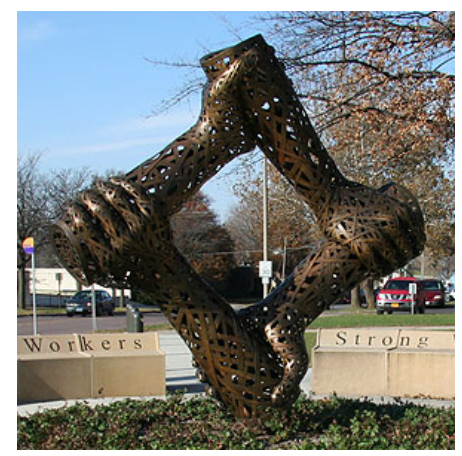

Fig. 9, Blacksmith, a memorial for the dedication in work, Omaha, USA

\section{Identity of the industrial cities in Europe:}

The geographical terrain has had a major role in the distribution of industries in Egypt. It was the social conditions that caused manufacturers to have a connection with their residents, and this made it difficult to move to places other than their hometowns. The economic conditions played a prominent role in the movement of craftsmen concerning the industrial cities in search of a better income and standards of living. The government tried to create new industrial cities by providing them with some livelihoods to attract workers, artisans and businessmen. It tried to emphasize the identity of these cities by building special features and artwork models to give a special model of distinction and uniqueness. Some models of the industrial cities in Egypt include Mahalla al-Kubra, Tenth of Ramadan, the Nag Hammadi and Marsa Alam.

The study revealed tha some of the models showing the identity of the industrial cities and the role of arts show the identity of these cities and their importance in the expression of the identity, the places and communities that practice industrial activities. It was as if it is a menfistation of presenteting their inner core; the psychological dynamics, social motives and the secret policy of the society. A mutual influence towards the identity of the industrial hometown has appread to expound on the communal, cultural, intellectual policies of the people in order to get to know their identity, heritage and beliefs. The cultural legacy in that sense serves as an essential part in confirming the industrial cities' identity. It is the finest way to record the hertiage and document the reality of the events. Urban spaces in the industrial cities are the means of spreding the cultural of its residentis and the policy of the responsible administration. Also, it shows to what extent the artist's senses are connected to the realistic and symbolic recording of the place' identity.

Marsa Alam City: It is one of the citiesin the Red Sea Governorate which was, during Pharaonic era and the Roman era, famous for gold mines, and the effects of that period still exist in the form of some of the Pharaonic inscriptions carved in the rocks. It is one of Egypt's rich reserves of gold ore areas, which lies in Alsukari mine in the Eastern Desert, which is one of the top 10 producing gold mines in the world. In May 2005 a company was established to continue the exploration in the region under the name of "Alsokary gold mines company"

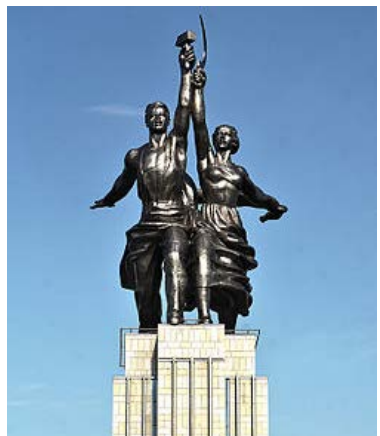

Fig.9, Worker and Kolkhoz Woman monument in Moscow, Russia. It was made from stainless steel by Vera Mukhina for the 1937 World's Fair in Paris

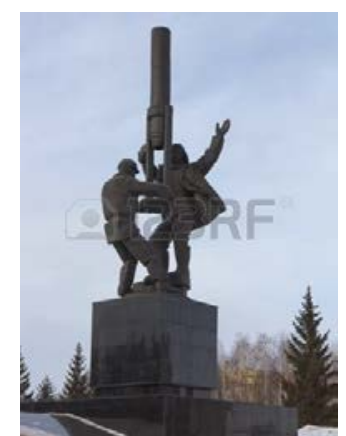

Fig. 10, A Statue of Two oil industry workers in the Almetyevsk Republic of Tatarstan Russia

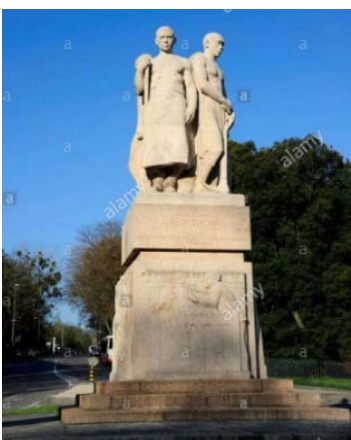

Fig. 11, Statue of workers, commemorating the International Labour Organisation in Geneva, Switzerland ${ }^{6}$

\footnotetext{
${ }^{6}$ http://www.alamy.com/stock-photo-statue-of-workers-commemorating-the-international-labour-organisation35793495.html
} 
A model for a monument in GDANSK, Poland. It is a memorial of the Fallen Shipyard Workers in front of Solidarity Square. The former President of Poland has considered that monument as of the victims of the communist regime ${ }^{7}$ (Fig. 12). It was held to commemorate the victims of the workers' revolution in Poland in December 1970, and it is known to be for the victims of the harbor- also called 'three crosses' commemorating the victims of the December of 1970 a ${ }^{8}$ (Fig. 13)

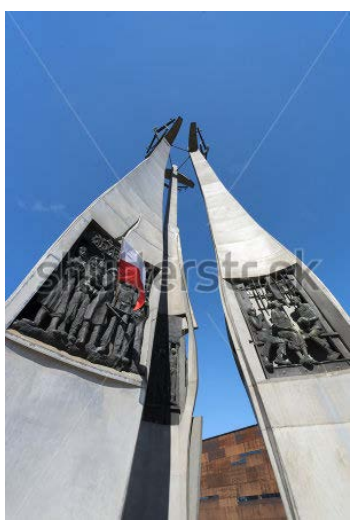

Fig. 12, memorial for the victims of the communist regime, Poland, August 2012 Solidarity Square in front of Gdansk's Shipyard. Former President of Poland
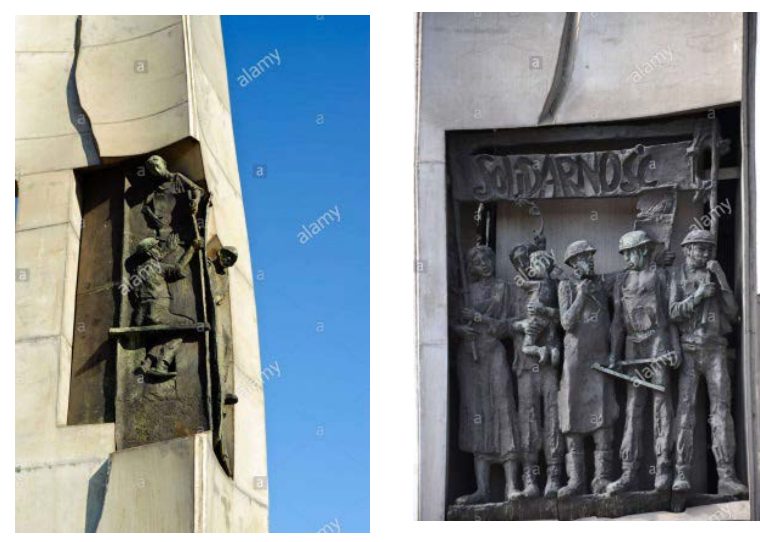

Fig. 13, memorial for the victims of the communist regime, Poland, August 2012 Solidarity Square in front of Gdansk's Shipyard. Former President of Poland

* A statue representing one of the American oil workers who worked with the British in 1943. He holds one of his tools powerfully and enthusiastically as the economy depends on this area on transformative industries and mining . The statue was carried out by the artist "Jay O'Melia" in "Nottinghamshire" England, UK ( Figure 14). It was done according to the German interest as an industrial power in Europe. They opened the German Museum of Technology which highlights the industrial revolution in Europe by showing some of the equipment of the first factories in the country and some of the machines of railways. The museum referred to aviation and the associated development of the motor industry as a large model of a plane that was put above the museum (Figure 15)

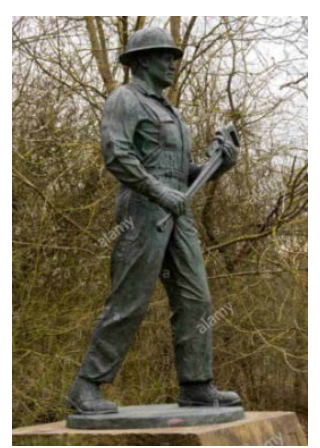

Fig. 14, An oil worker who worked with the British in 1934. The Oil Patch Warrior, a statue by Jay O'Melia Nottinghamshire, England, UK.

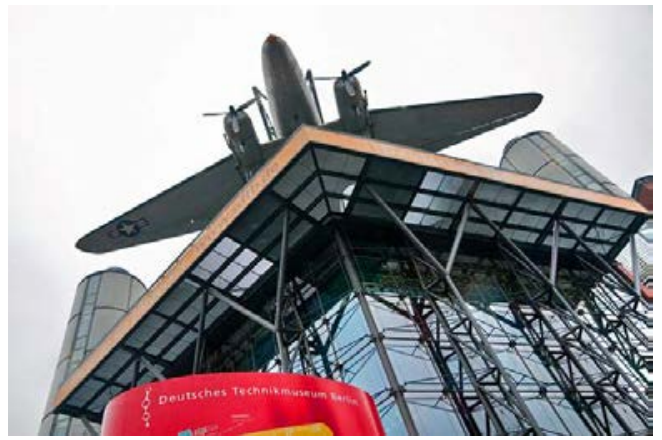

Fig. 15, A plane model above the German Museum of Technology, Germany

\section{Identity of the industrial cities in Egypt:}

The geographical terrain has had a major role in the distribution of industries in Egypt. It was the social conditions that caused manufacturers to have a connection with their residents, and this made it difficult to move to places other than their hometowns. The economic conditions played a prominent role in the movement of craftsmen concerning the industrial cities in search of a better income and standards of living. The government tried to create new industrial cities by providing them with some livelihoods to attract workers, artisans and businessmen. It tried to emphasize the identity of these cities by building special features and artwork models to give a special model of distinction and uniqueness. Some models of the industrial cities in Egypt include Mahalla al-Kubra, Tenth of Ramadan, the Nag Hammadi and Marsa Alam.

The study revealed tha some of the models showing the identity of the industrial cities and the role of arts show the identity of these cities and their importance in the expression of the identity, the places and communities that

\footnotetext{
${ }^{7}$ https://www.shutterstock.com/image-photo/gdansk-poland-monument-fallen-shipyard-workers332636903?src=2I9pOsr8N9AzyHD6PcY9mA-1-66

${ }^{8}$ https://www.poland.travel/en-gb/other/three-crosses-monument-in-gdansk
} 
practice industrial activities. It was as if it is a menfistation of presenteting their inner core; the psychological dynamics, social motives and the secret policy of the society. A mutual influence towards the identity of the industrial hometown has appread to expound on the communal, cultural, intellectual policies of the people in order to get to know their identity, heritage and beliefs. The cultural legacy in that sense serves as an essential part in confirming the industrial cities' identity. It is the finest way to record the hertiage and document the reality of the events. Urban spaces in the industrial cities are the means of spreding the cultural of its residentis and the policy of the responsible administration. Also, it shows to what extent the artist's senses are connected to the realistic and symbolic recording of the place' identity.

Marsa Alam City: It is one of the Red Sea Governorate' cities which was, during Pharaonic era and the Roman era, famous for gold mines. The aftereffects of that period still exist in the form of some of the Pharaonic inscriptions carved on rocks. It is one of the Egypt's rich reserves of gold ore areas, and it lies in Alsukari mine in the Eastern Desert. Alsukari is one of the top 10 producing gold mines in the world. In May 2005, a company was established to continue the exploration in the region under the name of "Alsokary gold mines company".

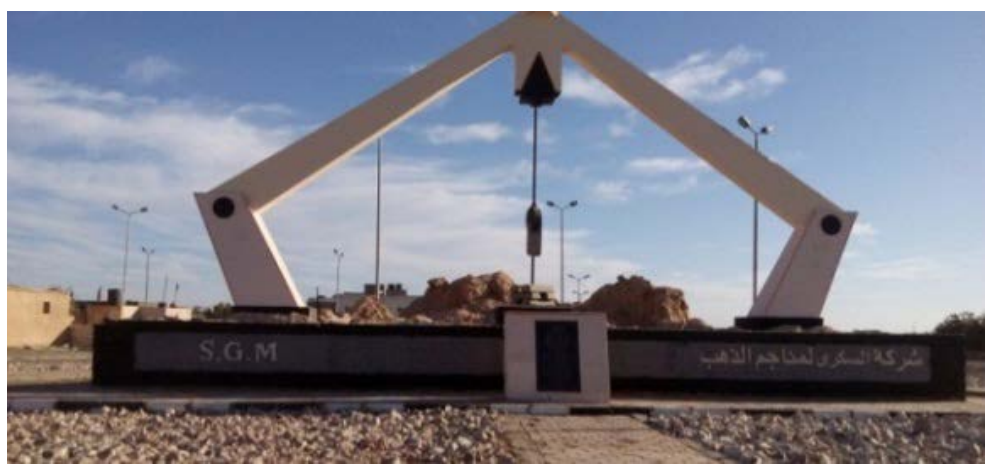

Fig.16, A structure showing the mining process in the Alsokary Mine in Marsa Alam, Egypt.

Fig 16 shows some elements related to the activity through the search for minerals, especially gold. It emphasizes the economic activity which assures the identity of the city and how this structure socially raises the spirit of the workers in this field.

It is a three-dimensional huge structure that highlights the strenuous effort they are doing in research, exploration and connection of workers and artisans to the place and the company. The company's appreciation for that and the appreciation of the government are meant to provide an opportunity to create that structure on the land of this city. It is a form of political support from the government to the important economic terms. It promotes the place by showing the workers' arts and skills. The monumen (in fig 16) is consisted of a lift of concrete which overhangs a piece of iron pipe clutching a gold bar. The city is famous for mining and quarrying the present mines of ore Quartz, Feldspar, Talc, Granite, Gypsum, and Limonite. The city has got a port for exporting mineral ores and laboratories to inspect the samples.

On a social level, it is residential, and there are already residence and inns for workers, schools and a field for games and tourist villages. Based on thess activities, the city's population awareness of mining methods and extraction to preserve their identity, to find significance of the artwork and to express the identity of the place have influenced everyone. It is a result of the on-site activity embodied in a structure expressing the value and appreciation of the city's identity.

Nag Hammadi: is one of the cities of Qena Governorate that has got the largest plant for the production of Aluminium in the Arab Middle East world. It has other significant plants to produce sugar cane and wood. The latter employs more than ten thousand workers, the vast majority of whom live in the residential city that is attached to the plant. The city in special in the sense of having the essential services, like schools, a hospital, a sports club . We find out the role of that art in highlighting the identity of the city by the statue of "civilization"- done by Haitham Amer (Fig. 17). The artist used the Egyptian woman as a symbol of the human being acting as the base of agriculture and industry. The statue pose is a in a motion-posture moving its left foot forward in a way that gives a sense of vigor and motivation to develop agriculture and industry. Symbols of the industry -a gear- and agriculture -branches- show the government's political efforts to bring beauty over the city with an artwork linked to the economic life of agriculture and industry. It is clear how the social factors spread the sense of connection to add a sense of pride. which shows its impact on of values and raising the spirit of nationalism and patriotism which influence the community, cultural, intellectual policy of the peoples to get to know their identity and heritage and beliefs their cultural legacy. 


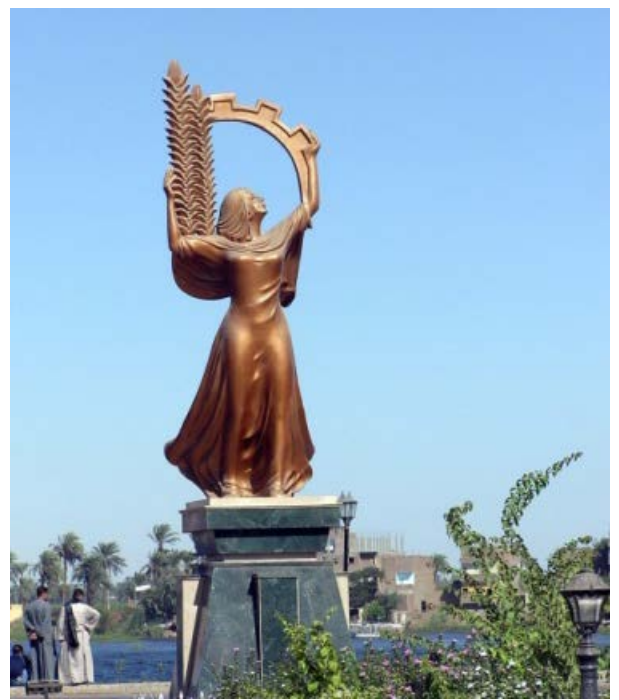

\section{Mahalla City:}

Fig. 17, "civilization" statue, Nag Hammadi, Egypt.

It is one of the cities of the Gharbeya Governorate, Egypt, and "it has the biggest factory for spinning and weaving in the Middle East. [5] It is " Misr Spinning and Weaving factory", which employs almost 27 thousand workers and employees, and the city's economy depends mostly on spinning, weaving, and other textile based services. A large number of the industrial and commercial activities are present as well such as oils, soap, electronics, carpets and adobe bricks and food industries. One of the artwork models which shows the identity of this industrial city is located at the entrance of the city of Mahalla (Figure 18). The designer adopted the gear to symbolize the identity of the industrial city, which is famous for its textile industry. Spinning and weaving industry are of the oldest industries known to for the ancient Egyptians; however, they developed the using of materials and machinery and trainings. Accordingly, the various government over history have played a vital role in appreciaitng and valuing the city's activities. Incorporating such symbols from the industrial environment contributes to increase craftsmen and worker's motivation and spreads the spirit of belonging to the city. It also assists in boosting the economic status implicitly in an exponential way.

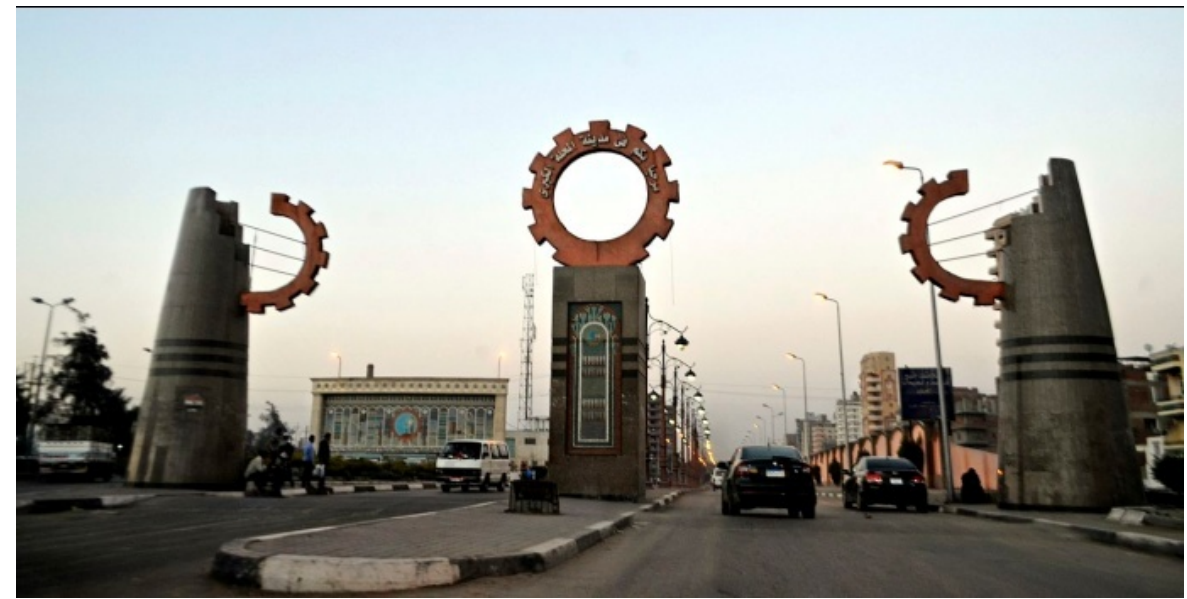

Fig. 18, Artwork structures (gears), Mahalla, Egypt

\section{Conclusion:}

Art has a positive role in assuring the identity of the industrial cities. There is a positive mutual influence between the social and cultural content of the members of the national industrial cities and arts. Identity is associated with social presence and it is a reflection of the values and communities seeking uniqueness, and distinction. By searching for the identity using art, communities and industrial cities urge their members to keep their heritage and preserve their values and work to establish affiliation to their home countries. 
Haitham Aamer Mahmoud Hussein / The Academic Research Community Publication

\section{References}

1. Michel, A. (2012). Transcending Socialization A Nine-Year Ethnography of the Body’s Role in Organizational Control and Knowledge Workers' Transformation. Administrative Science Quarterly,56(3), 325-368. doi:10.1177/00018392124375191993

SANTA FE SPRINGS, CA: February 12, 2014- "The... (n.d.). Retrieved August 30, 2017, from https://www.shutterstock.com/video/clip-5676593-stock-footage-santa-fe-springs-ca-february-the-oilfield-workerssculpture-by-carlos-terres-circa.html

2. The Lighthouse Hunters, Christine and Tom Cardaci. (n.d.). The Lighthouse Hunters. Retrieved August 30, 2017, from http://www.thelighthousehunters.com/nautical.htm

3. Overy, R. The Dictators: Hitler's Germany, Stalin's Russia, p260 ISBN 0-393-02030-4

4. Strathern, A., \& New Zealand Ministry for Culture and Heritage Te Manatu Taonga. (2013, July 09). 'Trawlermen' sculpture, Napier. Retrieved August 30, 2017, from https://teara.govt.nz/en/artwork/6277/trawlermen-sculpture-napier

5. GDANSK, POLAND - Monument of the Fallen Shipyard Workers is in front of the Center of Solidarnosc, on 24 september, 2015 Gdansk, Poland. It is memorial of workers victims of communist regime. (n.d.). Retrieved August 30, 2017, from https://www.shutterstock.com/image-photo/gdansk-poland-monument-fallen-shipyard-workers332636903?src=2I9pOsr8N9AzyHD6PcY9mA-1-66

6. 12 Top-Rated Museums and Art Galleries in Berlin | PlanetWare. (n.d.). Retrieved August 30, 2017, from http://www.planetware.com/germany/top-rated-museums-and-art-galleries-in-berlin-d-zzz-11.htm

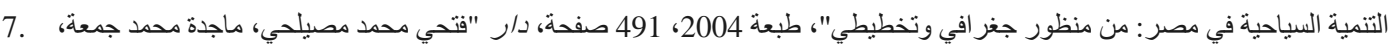

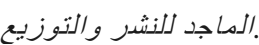

8. Monument to Labor. (n.d.). Retrieved August 30, 2017, from http://www.publicartomaha.org/art/info/83/Monument to Labor

9. Walls of Honor. (n.d.). Retrieved August 30, 2017, from http://www.passion-for-san-pedro.com/walls-of-honor.html 